\title{
Od Gradine do grada - stalni postav u nastajanju/muzealizacija kulturne povijesti
}

Tomić, Antonia; Zaninović, Joško

Source / Izvornik: Institucije povijesti umjetnosti : zbornik 4. kongresa hrvatskih povjesničara umjetnosti, 2019, 187 - 195

Conference paper / Rad u zborniku

Publication status / Verzija rada: Published version / Objavljena verzija rada (izdavačev PDF)

https://doi.org/10.31664/z4khpu.26

Permanent link / Trajna poveznica: https://urn.nsk.hr/urn:nbn:hr:254:780714

Rights / Prava: Attribution 4.0 International/Imenovanje 4.0 međunarodna

Download date / Datum preuzimanja: 2023-04-26

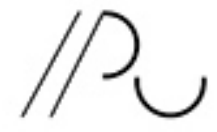

INSITIUTZZ POVIJEST UMJETNOSI
Repository / Repozitorij:

PODEST - Institute of Art History Repository

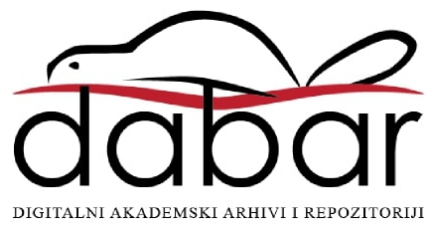




\section{Od Gradine do grada-stalni postav u nastajanju/ muzealizacija kulturne povijesti}

„Muzej Drniške krajine je u potpuno obnovljenoj zgradi dobio dobro opremljene radne prostore, čuvaonice i izložbene prostore. Postavljen je tek dio Meštrovićeve zbirke, a posao izrade koncepcije za novi stalni muzejski postav tek se očekuje", citat je iz članka objavljena r999. godine. ${ }^{1}$ Tijekom Domovinskog rata muzej je prilično stradao, neposredno nakon Oluje zatečena je ruševna muzejska zgrada, kaotično razbacana dokumentacija, oštećena ili potpuno uništena građa, a velik je dio muzejskih predmeta pokraden (sl. I, 2). ${ }^{2}$ Do I999. godine obavljeni su primarni građevinski zahvati, nakon kojih je omogućeno provođenje barem dijela muzejskih djelatnosti unutar muzejske zgrade.

U međuvremenu je muzeju promijenjeno ime u Gradski muzej Drniš, a očekivani radovi na izvedbi stalnoga postava započeli su petnaestak godina poslije, 20I4. godine te se aktivno provode i u trenutku pisanja rada. Dovršetak radova očekuje se, ovisno o dinamici kojom će pristizati novac iz Ministarstva kulture RH, za dvije do tri godine.

Izvedba stalnoga postava muzeja zahtjevan je i opsežan posao koji simbolično potvrđuje uspostavljanje kontinuirane komunikacije s posjetiteljima i opstojnost same institucije. Stalni postav ima ulogu svojevrsna glasnogovornika ustanove. ${ }^{3} \mathrm{Za}^{-}$ daća je muzejskih kustosa vješto uspostavljanje komunikacije između muzejskih predmeta i muzejskih posjetitelja kako bi se na što bolji način ostvarilo posredovanje baštine. ${ }^{4}$ Međutim, u općim gradskim muzejima regionalnoga tipa kao što je Gradski muzej Drniš nužno je iznaći pravi način za muzealizaciju konteksta i simboličkih vrijednosti kako bi se postiglo da lokalno stanovništvo muzejski stalni postav doživljava kao nešto blisko i svoje. Pri promišljanju stalnoga postava vodila nas je težnja da svaki dolazak u muzej u posjetitelja probudi želju za povratkom te da se izbjegne frustracija uzrokovana nerazumijevanjem izloženog sadržaja ili zamor prenatrpanošću materijalom. ${ }^{5}$ Tijekom izrade muzeografskog koncepta ${ }^{6}$

\section{Antonia Tomić Joško Zaninović}

Antonia Tomić Gradski muzej Drniš gradski.muzej.drnis@gmail.com

https://orcid.org/oooo-0oo3-4077-807I

Joško Zaninović

Javna ustanova Nacionalni park Krka josko.zaninovicı@gmail.com

https:/orcid.org/oooo-ooo3-4077-807I
I JOZEFINA DAUTBEGOVIĆ, VLADIMIRA PAVIĆ, Novi stalni postavi poslije Domovinskog rata, u: Informatica museologica, 30, I/4 (I999.), 5-6, 5 .

2 Djela Ivana Meštrovića bila su ukradena, a pronađena su nakon Domovinskog rata na kninskoj tvrđavi.

3 Opisujući složenost izvedbe stalnog postava i njegovo značenje, Ivo Maroević stalni postav naziva legitimacijom svakog muzeja. IVO MAROEVIĆ, Interdisciplinarnost i stalni postav u muzejima, u: Informatica museologica, 20, I/2 (I989.), I4-I8, I4.

4 O komunikacijskoj ulozi muzeja i nužnosti da se više pažnje posvećuje potrebama posjetitelja te oblikovanju ugodne muzejske atmosfere pisala je i Eilean Hooper-Greenhill sredinom devedesetih godina 20. stoljeća, a njezina su razmatranja aktualna i danas. EILEAN HOOPER-GREENHILL, Museums and their Visitors, London \& New York, Routledge, I994., I996.; TONČIKA CUKROV, Eilean Hooper-Greenhill, Muzeji i njihovi posjetitelji („Museums and their Visitors”), u: Informatica museologica, 27, 3/4 (I996.), 99-ıoo.

5 Jednu od najpotpunijih definicija stalnoga muzejskog postava dao je Ivo Maroević: „Karakteristike stalnog postava su: stabilnost tematskog dosega, trajnost u vremenu i prostoru, strukturiranost i dostupnost svim razinama posjetilaca, definiranost i artikuliranost poruke, odraz jasnoće zbirnog fonda, komplementarnost s povremenim izložbama [...].” IVO MAROEVIĆ, Stalni postav-objektivizacija muzejskog zbirnog fonda, u: Informatica museologica, 2I, I/2 (I990.), 89-9o, go.

6 Autori muzeografskog koncepta stalnog postava Gradskog muzeja Drniš su Joško Zaninović (muzejski savjetnik), Davor Gaurina (viši kustos) i Antonia Tomić (kustosica). 

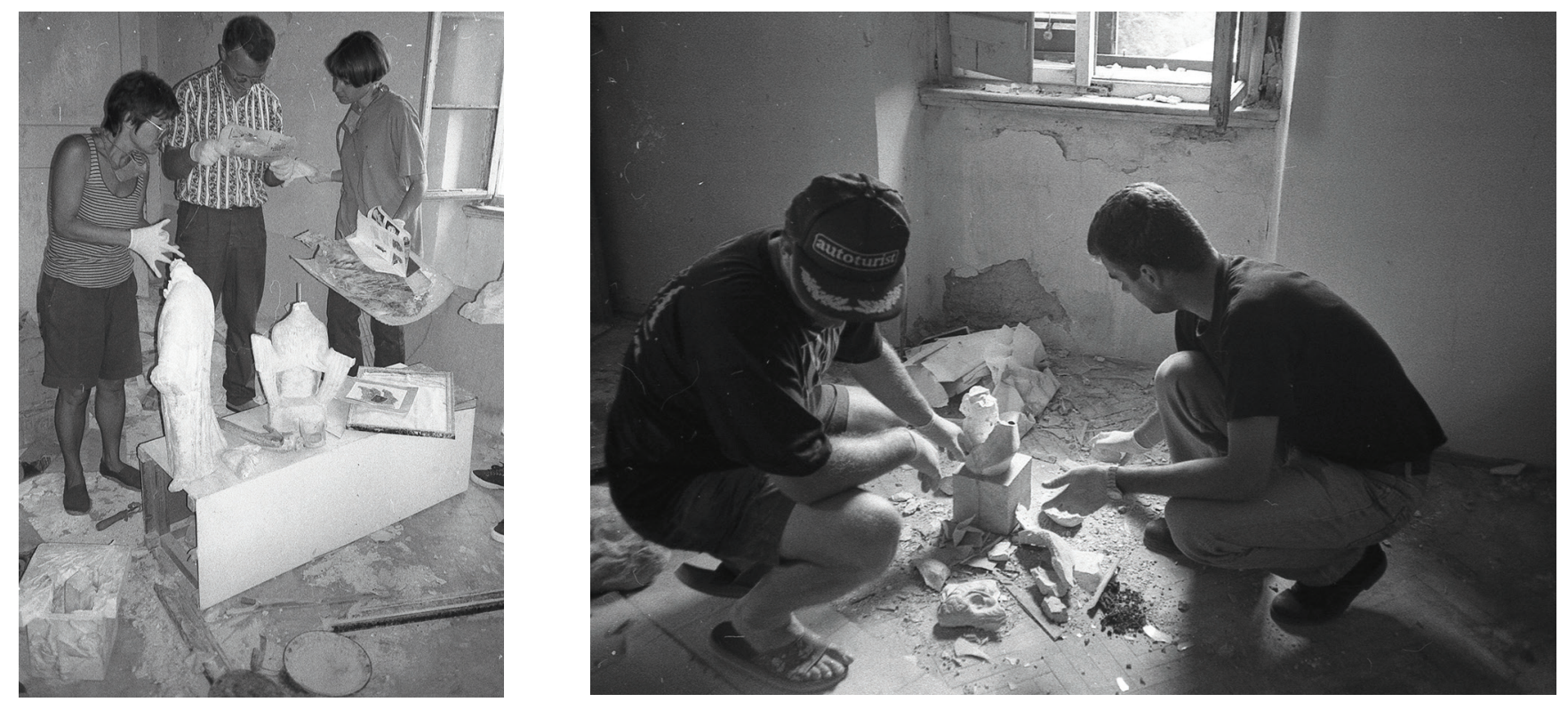

Slika I

Gradski muzej Drniš, 6. kolovoza I995., restauratorica Nada Bogdanović, kustos Davor Gaurina i arheologinja Nataša Zaninović raščišćavaju zatečeni nered foto: S. Ferić

\section{Slika 2}

Gradski muzej Drniš, 6. kolovoza I995., arheolozi Željko Krnčević i Joško Zaninović u opustošenom muzeju pokušavaju sakupiti krhotine uništene gipsane skulpture foto: S. Ferić

\section{Slika 3}

Tlocrt s naznačenim izložbenim dvoranama Gradskog muzeja Drniš izradio: Ured ovlaštenog arhitekta Zoran Popović Šibenik, 20I4.

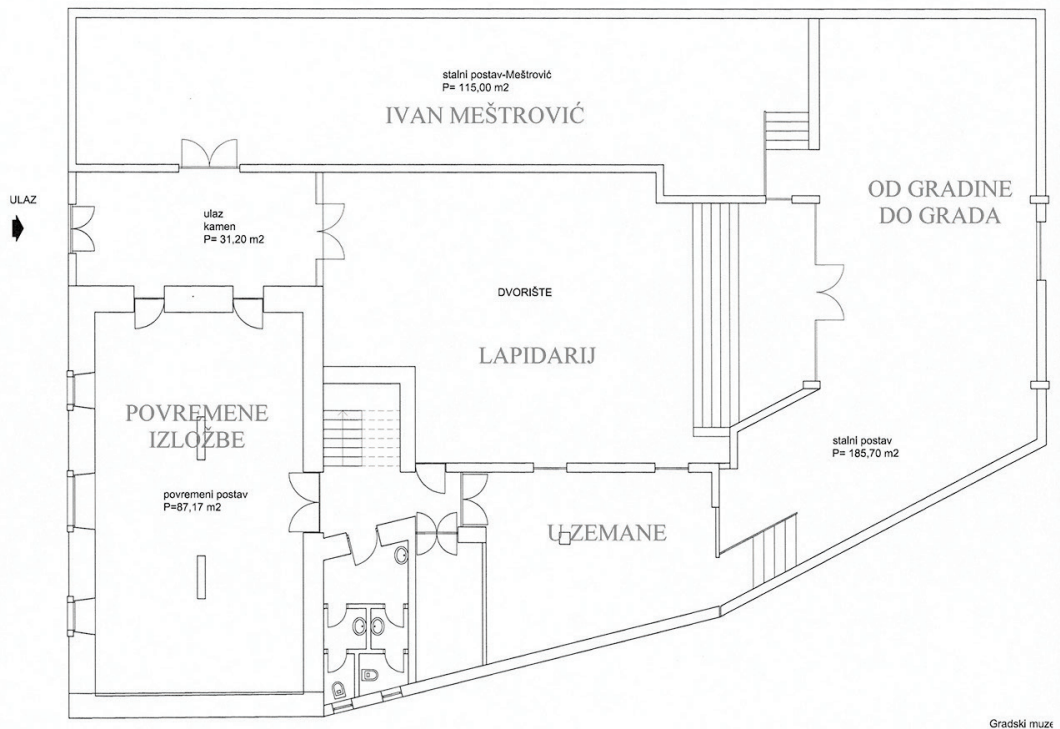

uzeli smo u obzir raznoliku strukturu muzejskih posjetitelja te smo nastojali ostvariti višeslojnost $\mathrm{i}$ interdisciplinarnost stalnoga postava, koji će istovremeno omogućavati cjelovitu priču, ali i mogućnost višestrukih segmentnih čitanja. ${ }^{7}$

Stalni postav Gradskog muzeja Drniš proteže se kroz tri dvorane koje u obliku slova U uokviruju atrij (sl. 3). U prvoj dvorani naglašene longitudinalnosti smještena je najvažnija umjetnička zbirka muzeja-Zbirka Ivana Meštrovića. Potom slijedi dvorana posvećena kulturnoj povijesti nazvana „Od Gradine do grada", najsvojstveniji dio stalnih postava gradskih muzeja te ujedno tema ovoga rada. Na nju se naslanja mali prostorni isječak posvećen Domovinskom ratu na drniškom području.
7 „Treba raditi višeslojne izložbe u kojima će svaki posjetitelj u skladu sa svojim obrazovanjem, interesima, u skladu sa svojom dobi pronaći nešto za sebe." ŽELIMIR LASZLO, Zašto su muzeji dosadni?-Rasprava o izložbama, u: Informatica museologica, 3I, 3/4 (200I.), 98-10о, 98 . 
Potom slijedi dvorana nazvana „U zemane”, u kojoj je prezentirano nekoliko tema iz svakodnevice lokalnoga stanovništva, narodno ruho, prikazani počeci rudarstva i industrijalizacije te početak djelovanja organiziranih kulturnih i sportskih društava. Prostor atrija iskorišten je za smještaj lapidarija u kojem se kronološki redaju kameni spomenici od prapovijesti do Ig. stoljeća.

Kulturno-povijesni dio stalnoga postava „Od Gradine do grada” najsloženiji je dio stalnoga postava i muzeološki najzahtjevniji. Predmeti su birani iz gotovo svih muzejskih zbirki, ${ }^{8}$ a među njima su znatne razlike u tipologiji, kronologiji i tematici odnosno kontekstu (sl. 4). Inicijalna pitanja na koja smo nastojali dati odgovor prije nego što smo pristupili izradi i razradi muzeografskoga koncepta bila su na koji način izabrati i smjestiti muzejske predmete da na najbolji način pričaju priču o gradu Drnišu i drniškome području od prvih tragova čovjekove prisutnosti pa do današnjih dana, a da izloženi koncept bude pristupačan svim dobnim skupinama te da istovremeno bude zanimljiv izletnicima/turistima i lokalnome
8 Zbirke iz kojih su izabrani predmeti za dvoranu „Od Gradine do grada” jesu: Arheološka zbirka; Kulturnopovijesna zbirka; Zbirka oružja i vojne opreme; Zbirka starih knjiga - do I86o. godine; Zbirka starih zemljovida, grafika, starih fotografija i razglednica; Zbirka starog novca, medalja, odlikovanja, znački i plaketa; Zbirka suvremene umjetnosti. Pored nabrojenih, muzej posjeduje još i Zbirku Ivana Meštrovića koja je izložena samostalno zbog svoje imanentne umjetničke vrijednosti, ali i uloge Ivana Meštrovića u osnivanju muzeja.

Kronološki

\begin{tabular}{|c|c|c|c|c|c|c|c|}
\hline Pretpovijest & Antika & \multicolumn{2}{|c|}{ Srednji vijek } & Osmansko doba & Mletačko doba & Austrijsko doba & 2o. stoljeće \\
\hline \multicolumn{4}{|l|}{ Tematski } & \multicolumn{4}{|c|}{$\downarrow$} \\
\hline \multicolumn{2}{|c|}{ Prvi tragovi života } & \multicolumn{2}{|c|}{ Srednjovjekovna gradina } & \multicolumn{2}{|c|}{ Razvoj urbanog rastera } & \multicolumn{2}{|c|}{ Razvoj građanskog života } \\
\hline \multicolumn{8}{|l|}{ Tipološki } \\
\hline $\begin{array}{l}\text { Paleontološka } \\
\text { građa }\end{array}$ & $\begin{array}{l}\text { Arheološka } \\
\text { građa }\end{array}$ & $\begin{array}{l}\text { Povijesna } \\
\text { grada }\end{array}$ & $\begin{array}{l}\text { Umjetnička } \\
\text { građa }\end{array}$ & $\begin{array}{l}\text { Tehničk } \\
\text { grada }\end{array}$ & Vojna gra & $\begin{array}{l}\text { Audiovizualı } \\
\text { grada }\end{array}$ & $\begin{array}{l}\text { Knjižna } \\
\text { grada }\end{array}$ \\
\hline
\end{tabular}

Slika 4

Razrada muzejske građe prema kronologiji, tematici i tipologiji 
stanovništvu. Dogovorno je odlučeno da će se muzejska građa slagati kronološko-tematski isprepleteno, a iz kronologije je uvelike proizašla i razdioba na tematske cjeline (sl. 5):9

I. Prvi tragovi čovjekove prisutnosti i organizirano naseljavanje područja (Prapovijest-antika-srednji vijek)

2. Gradina-graditeljske faze, promjene stilova, vlastodržaca/ država i namjene (Osmansko doba-Mletačko doba-Austrijsko doba)

3. Oblikovanje povijesne jezgre grada Drniša (I9. i 20. stoljeće, oblikovanje suvremenog grada-razvoj građanskog života)

Naziv cjeline „Od Gradine do grada” nametnuo se gotovo sam od sebe, jer sažima kratko i jezgrovito cijeli koncept. Arheološka sondiranja rezultirala su pronalaskom sitnoga arheološkog materijala na širem području utvrde Gradine kronološkog raspona od prapovijesti do vremena austrijske vladavine. Širenje naselja izvan zidina Gradine započinje već u osmanskom razdoblju, što je razvidno iz onovremenih grafika (sl. 6), ${ }^{10}$ već tijekom mletačke vladavine utvrda pomalo gubi obrambenu ulogu i počinje gradnja nastambi izvan zidina,${ }^{11}$ a tijekom austrijske vladavine oblikuje se urbana struktura današnjega grada (sl. 7). ${ }^{12}$ Gradina je simbolično postala ishodište današnjega grada, a ujedno i doslovno ugrađena u današnji grad jer je poslužila kao kamenolom za brojne obližnje kuće.

Arhitektonsko oblikovanje muzejskih dvorana uvelike utječe na mogućnost ostvarivanja zamišljenoga muzeografskog koncepta, a jednako je važno i likovno rješenje postava. Pred autore arhitektonskog i likovnog rješenja postavljeni su ovi zahtjevi:

- čistoća i neopterećenost oka / dinamiziranje prostora

- sugeriranje kretanja / izbjegavanje barijera

- smještaj velikog broja predmeta / izbjegavanje pretrpanosti prostora

- sučeljavanje tradicionalnoga i suvremenoga muzejskoga pristupa:

- vitrine vs. multimedijalna oprema

- digitalizacija papirne građe

- izrada 3D-modela arhitekture

- virtualna interakcija s posjetiteljima

- inkorporacija prepoznatljivoga baštinskoga znaka (S-linija/ spirala)

Binarne opozicije s kojima se trebaju nositi projektanti i dizajneri samo se naizgled čine nespojivima. ${ }^{13}$ Vještina balansiranja zadanim parametrima odražava njihovu upoznatost $\mathrm{s}$ aktualnom muzejskom praksom. Arhitektonskim rješenjem dvorana je osmišljena kao prostorija jednostavnih čistih linija i čistih bijelih ploha dinamizirana tek crnim trakama na stropu unutar kojih je smještena ventilacija i rasvjeta. S obzirom na postojeći raspored dvorana, dodatne arhitektonske barijere nisu bile potrebne. Likovnim rješenjem predloženo je da se postav oblikuje kao svojevrsna vremenska lenta, gotovo kao putovanje kroz prošlost drniškoga kraja. Postojanje pak triju ulaza u dvoranu omogućuje posjetiteljima da sami prema vlastitom nahođenju organiziraju obilazak izložaka, bilo nasumično, bilo prateći predloženi kronološki redoslijed. Vitrine trebaju udomiti velik broj predmeta, no zato su predloženi

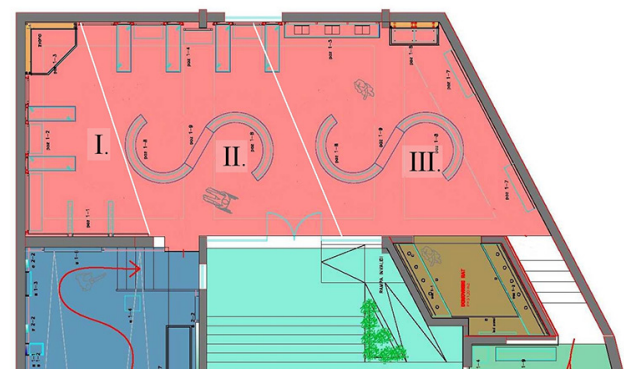

Slika 5

Tlocrt dvorane „Od Gradine do grada" s označenim tematskim cjelinama i shematskim prikazom rasporeda vitrina izvor: Muzeografski koncept stalnoga postava Gradskog muzeja Drniš, 2014.
9 IVO MAROEVIĆ, Muzejski predmet kao povijesni izvor i dokument, u: Informatica museologica, 36, I/2 (2005.), 54-57. Ivo Maroević izdvaja prostor, vrijeme i društvo kao tri osnovne dimenzije koje određuju značenjsku širinu i informativnost predmeta, a navedene dimenzije moguće je iščitati i iz tematskih cjelina dvorane „Od Gradine do grada”. Zajednički pak život raznorodnih i raznovremenih muzejskih predmeta u novome muzeološkom kontekstu „otvara nove mogućnosti prikaza znanja” neovisno o vrsti/ tipu. Stoga tip/vrsta predmeta nije ni bila presudna pri izboru eksponata.

IO KORNELIJA JURIN STARČEVIĆ, Islamsko-osmanski gradovi dalmatinskog zaleđa: prilog istraživanju urbanog razvoja u i6. i I7. stoljeću, u: Radovi Zavoda za hrvatsku povijest, 38 (2006.), II3-I54, I22.

II KARLO KOSOR, Drniš pod Venecijom, u: Povijest Drniške krajine, (ur.) Ante Čavka, Split, I995., I8I-248, Igo.

I2 RADOSLAV TOMIĆ, Smjernice za obnovu spomeničke baštine Drniša, u: Etnologica Dalmatica, 3 (1993.), 8I-83, 8I.

I3 Autor arhitektonskog rješenja je Ured ovlaštenog arhitekta Zorana Popovića, Sibenik, a dizajn likovnog postava izradio je grafički studio iDesign iz Šibenika. 

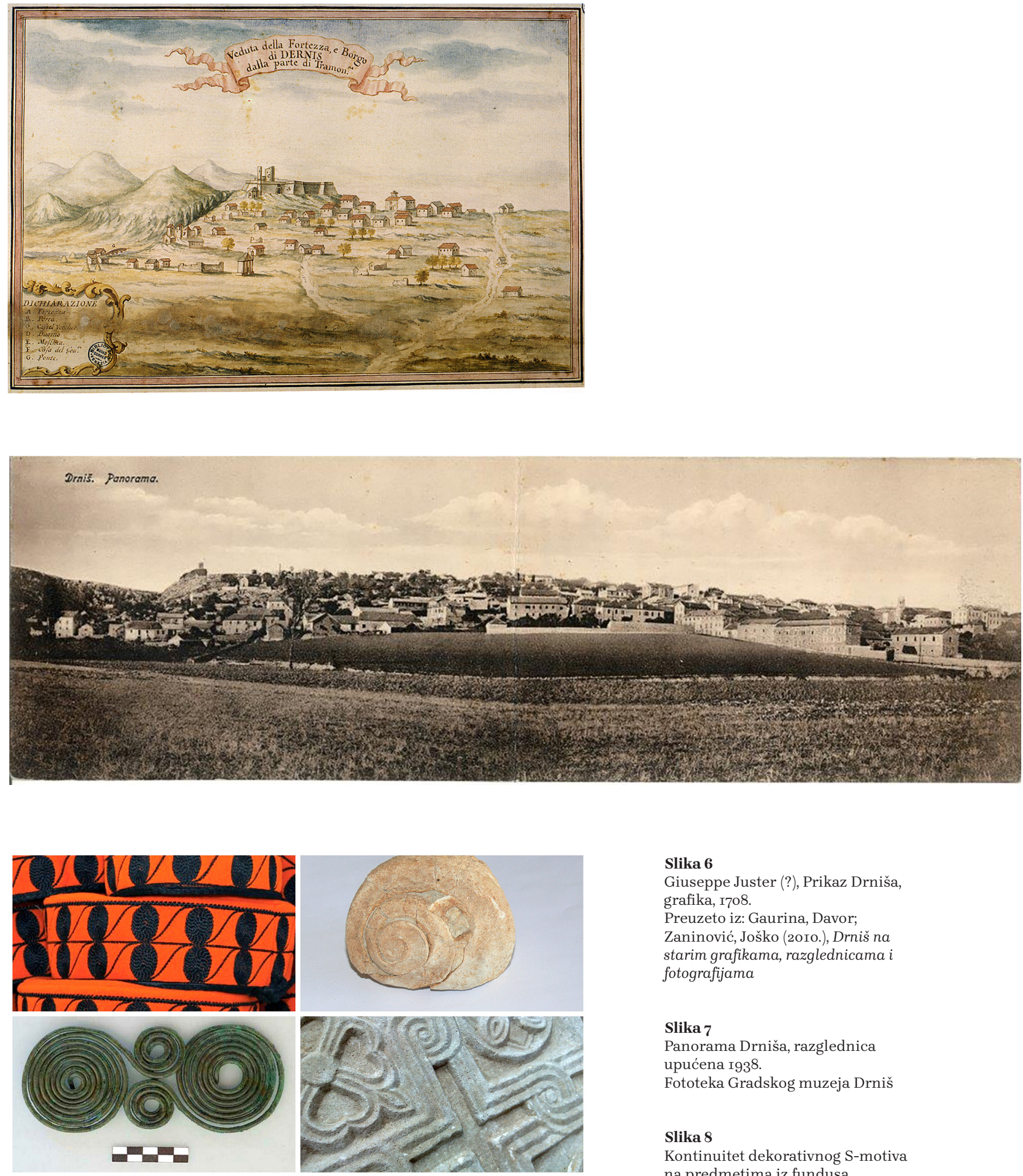

Slika 6

Giuseppe Juster (?), Prikaz Drniša, grafika, I708.

Preuzeto iz: Gaurina, Davor;

Zaninović, Joško (20Io.), Drniš na starim grafikama, razglednicama $i$ fotografijama

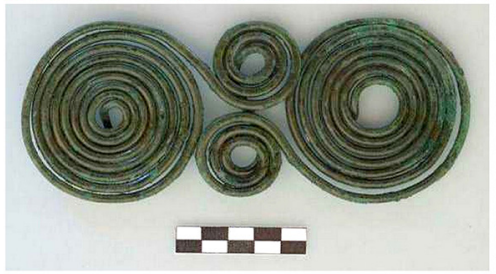

\section{Slika 7}

Panorama Drniša, razglednica upućena I938.

Fototeka Gradskog muzeja Drniš

\section{Slika 8}

Kontinuitet dekorativnog S-motiva na predmetima iz fundusa Gradskog muzeja Drniš

(Drniška kapa-dio narodne nošnje, okamina puževe kućice s planine Promine, antička fibula iz pećine Jazinka u kanjonu rijeke Krke, ulomak ranokršćanskog pluteja iz sela Gradac) 


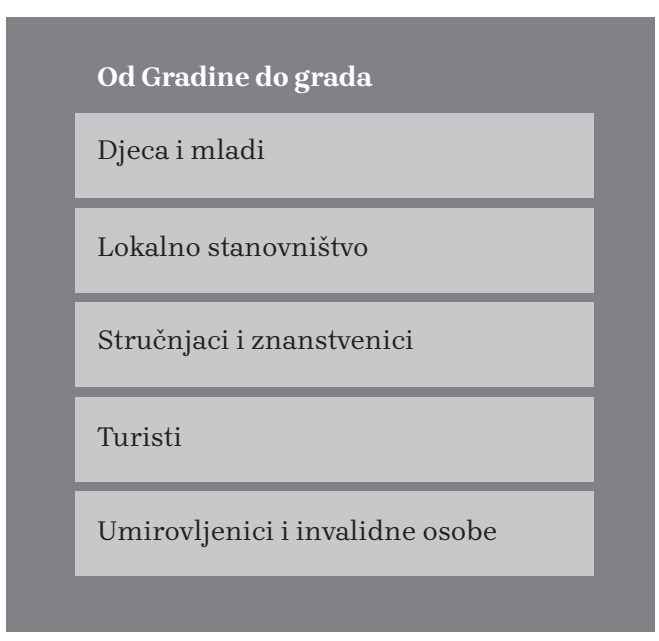

transparentni materijali koji neće dodatno opterećivati oko. Izlaganje arhitektonskih rekonstrukcija, masovne građe poput fotografija i publicistike, osjetljive građe poput negativa i antiknih knjiga, izvest će se posredstvom multimedijskih alata i opreme. Multimedija je u muzeju današnjice nužan komunikacijski alat s posjetiteljima, omogućuje izravniji kontakt, lakše posredovanje muzejske poruke i veću interakciju, posebno s mlađim generacijama.

Poseban zahtjev bio je i oblikovanje prepoznatljivoga baštinskog znaka za svaku dvoranu. Za dvoranu „Od Gradine do grada” odabran je zavojiti S-motiv koji se kontinuirano proteže kao dekorativni motiv na predmetima od prapovijesti do 20. stoljeća (sl. 8). Kreativnim prijedlogom dviju vitrina S-motiva po sredini dvorane udovoljeno je zahtjevu prepoznatljivoga znaka, a istovremeno je dobiveno više vitrinskoga prostora za izlaganje predmeta.

Sav trud muzealaca oko izrade muzeografskog koncepta usmjeren je prema muzejskim posjetiteljima kao krajnjim korisnicima, na što upućuje jedna od recentnijih definicija ICOM-a. ${ }^{14}$ Temeljem dosadašnjih evidencija posjetitelja razradili smo ciljane skupine kojima su namijenjeni stalni postav i programski sadržaji koji iz njega proizlaze (sl. 9). Svaki posjetitelj, bilo da dolazi u skupini ili pojedinačno, od muzeja ima određena očekivanja. Andre Gob i Noémie Drouguet razdijelili su očekivanja posjetitelja na šest kategorija: muzej kao mjesto dokolice i zabave; muzej kao mjesto otkrića; muzej kao mjesto uspomena i sjećanja; muzej kao kulturni označitelj; muzej kao turistička aktivnost; muzej kao obred..$^{15}$ Navedenim kategorijama u kontekstu našega gradskog muzeja mogla bi se dodati i ova-muzej kao čuvar/graditelj lokalnoga identiteta.

Uzimajući u obzir raznolika očekivanja i raznovrsnost posjetitelja budućega stalnog postava izrađeni su okvirni programi za svaku skupinu koji će se detaljnije razrađivati neposredno prije nego što stalni postav zaživi (sl. Io). Pozitivan trend kretanja turističkih dolazaka i noćenja na području Grada Drniša (sl.

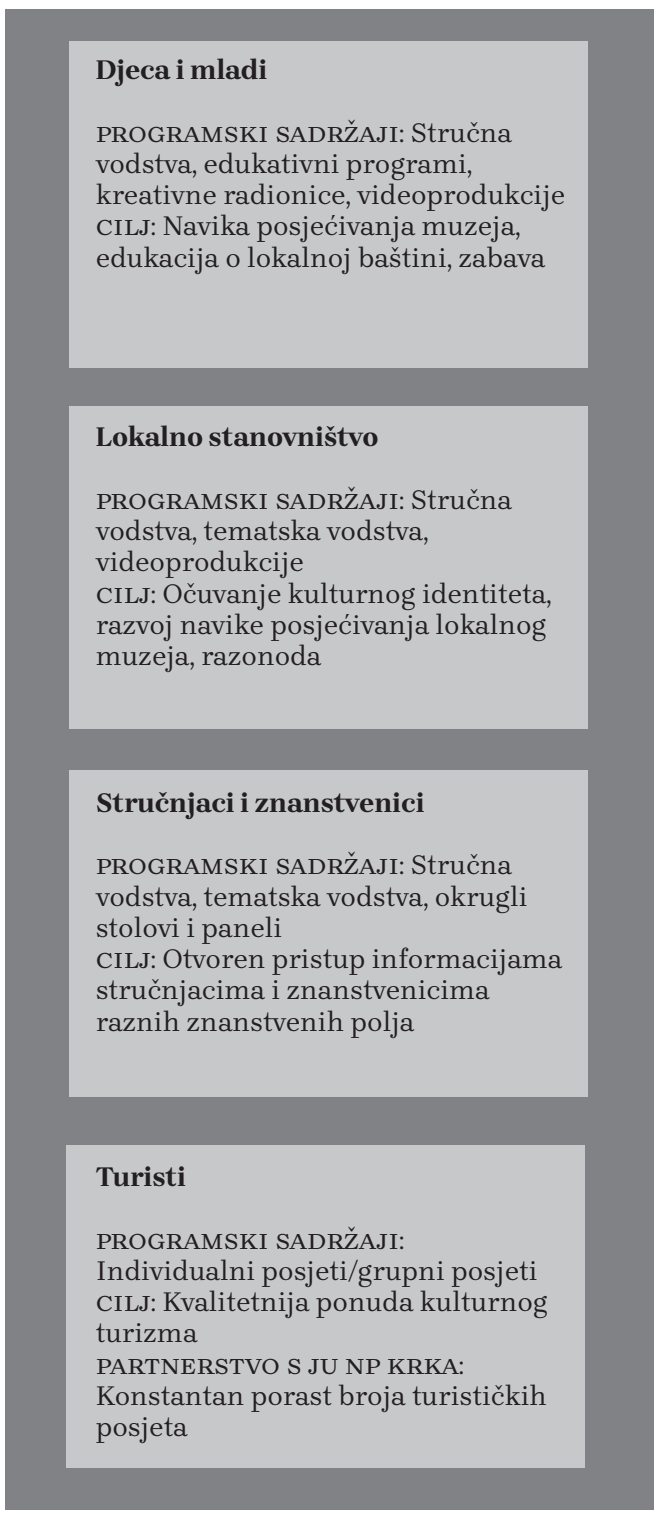

Slika 9

Ciljane skupine posjetitelja za stalni postav Gradskog muzeja Drniš

Slika Io

Programski sadržaji za različite skupine posjetitelja

I4 „Muzej je stalna, neprofitna ustanova u službi društva i njegova razvitka, otvorena javnosti, koja sabire, čuva, istražuje, komunicira i izlaže u cilju proučavanja, izobrazbe i zabave." Izvadak iz ICOM-ova statuta preuzet iz: ANDRE GOB, NOÉMIE DROUGUET, Muzeologija: povijest, razvitak, izazovi današnjice, Zagreb, 2007., 4I.

I5 ANDRE GOB, NOÉMIE DROUGUET (bilj. I4), 69-70. 


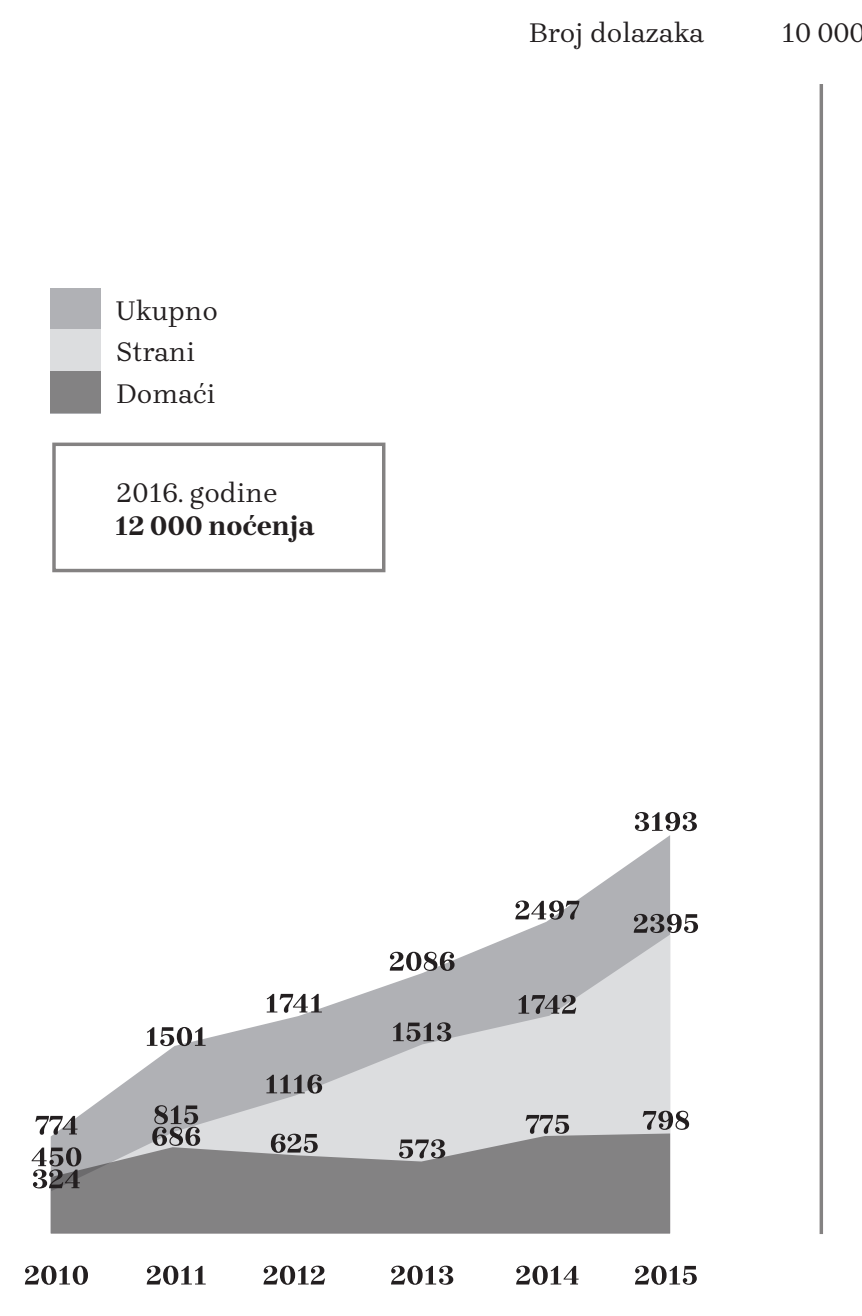

Trend kretanja dolazaka turista po godinama
Broj noćenja

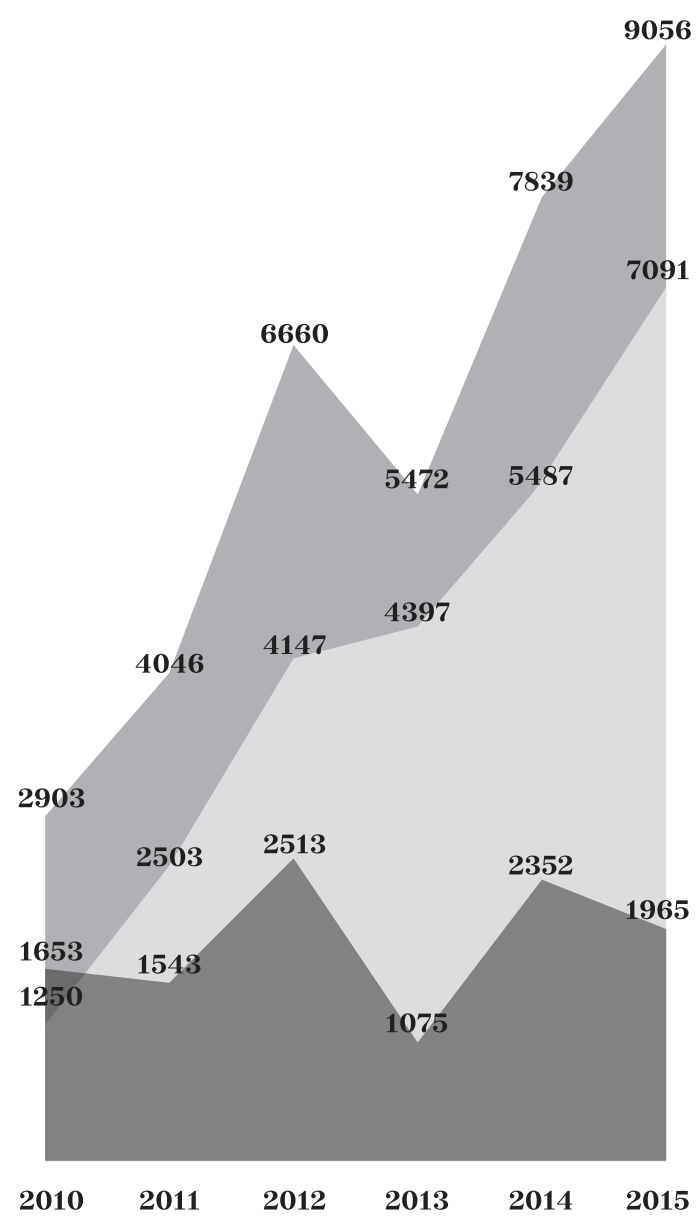

Trend kretanja broja noćenja turista po godinama

\section{Slika II}

Trend kretanja dolazaka

i broja noćenja turista

od 20Io. do 20I6. godine za područje Grada

Drniša, podatke ustupila

Turistička zajednica

Grada Drniša 
II) te rušenje rekordnog broja turističkih posjeta JU NP Krka iz godine u godinu pružaju nam osnovu za razradu planova za budućnost.

Priča ispričana kroz stalni postav Gradskog muzeja u Drnišu zbog arhitektonske zadanosti prostora nužno mora biti sažeta i jezgrovita s pomno odabranim predmetima preko kojih se omogućuje što rječitije uspostavljanje komunikacije s posjetiteljima. Sretna je okolnost ta da je širina teritorijalnog obuhvata i dobra suradnja s lokalnom zajednicom, crkvenim predstavnicima i javnim ustanovama omogućila formiranje triju (uz četvrtu u nastajanju) vanjskih, dislociranih muzejskih zbirki kojima se nadopunjuju teme arheološke, etnografske, sakralne i industrijske baštine kako bi se zainteresiranim posjetiteljima pružila opširnija slika (sl. I2). Nedaleko muzejske zgrade pored rijeke Čikole smještena je Stara mlinica, obnovljena u sklopu projekta Razvoj turizma na rubnim dijelovima Nacionalnog parka Krka, financirana iz EU-fondova. U njoj je na prvome katu rekonstruiran mlinarev stan, u kojem je smješten dio muzejskih etnografskih predmeta povezanih uz tradicionalno (ruralno) kućanstvo, u prizemlju je postavljena izložba fotografija Od zrna do pogače, a predviđeno je rekonstruiranje mlinskog pogona kako bi se pojačala atraktivnost postava.

U selu Gradac, nedaleko Drniša, prilikom arheoloških istraživanja poduzetih prije faksimilne obnove u ratu razrušene crkve, ispod crkve otkrivena je starohrvatska bazilika. Kako bi se omogućila prezentacija apside bazilike, prostor ispod crkve proširen je i u njemu je uređen mali župni galerijski prostor za koji su koncept radili djelatnici Gradskog muzeja u Drnišu.
Slika I2

Prikaz vanjskih zbirki

Gradskog muzeja Drniš
Etnografija

Stara Mlinica na Čikoli (Drniš)
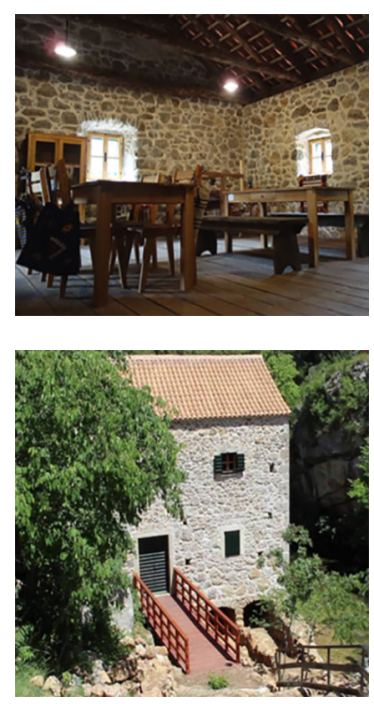

Crkvena povijest

Kripta crkve Male Gospe

(Župni muzej Gradac)
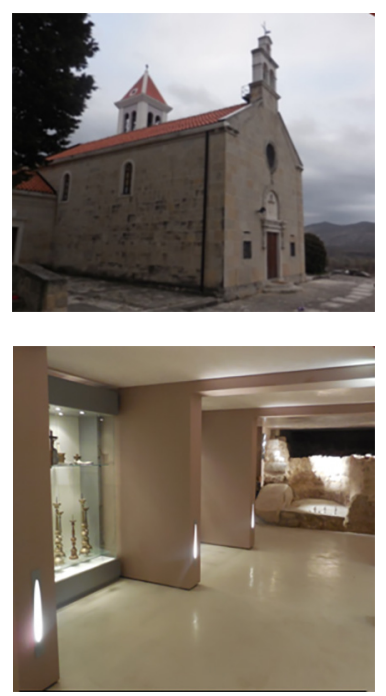

Arheologija

Arheološka zbirka Burnum (Puljani)
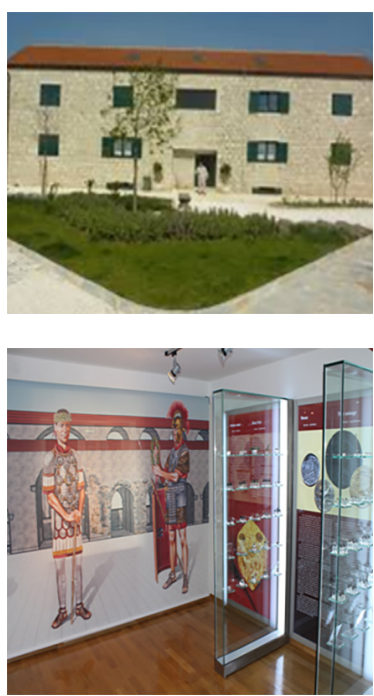

Industrijska baština

Dom kulture u Siveriću/

Rudarski dom

Među eksponatima su kameni spomenici, zavjetni predmeti, crkveno posuđe i etnografski predmeti, a Gradski muzej ustupio je tri rada Ivana Meštrovića-gipsanu skulpturu Mojsija, brončanu pokaznicu i brončanu skulpturu Glava opatice.

Na području JU NP Krka u selu Ivoševci od 2003. godine traju sustavna arheološka istraživanja rimskog vojnog logora Burnuma. Slijedom sretnih okolnosti bivši vojni kompleks u selu Puljani, sa suprotne strane rijeke Krke, pripao je JU NP Krka te je jedna od zgrada namijenjena za smještaj i izvedbu stalnog postava Arheološke zbirke Burnum. Muzeografski koncept osmislili su djelatnici Gradskog muzeja Drniš.

Siverić, selo u podnožju planine Promine, nekada je bilo okosnica industrijalizacije područja cijele županije zahvaljujući rudniku mrkog ugljena. Podsjetnik na nekadašnju rudarsku prošlost tek su poneke rudarske zgrade, zapušteni kopovi i pokoji zaboravljeni vagoncin. U tijeku je provedba Integriranog programa obnove kulturne baštine Grada Drniša, koji obuhvaća pripremu i izradu projektne dokumentacije za četiri objekta, među kojima je i Dom kulture u Siveriću. Ideja je da nekadašnji Dom kulture postane Rudarski dom u kojem će se oživiti i sačuvati priča o siverskom rudarstvu, gradnji željezničkih pruga i industrijalizaciji područja.

Planovi za budućnost opsežni su i ambiciozni, preostaje nam vjerovati da će nam sreća biti naklonjena i da ćemo ih uspjeti provesti u djelo.

\section{() (1)}

Od Gradine do grada-stalni postav u nastajanju/muzealizacija kulturne povijesti / Antonia Tomić/Joško Zaninović / CC BY / 4.0

DOI: https://doi.org/Io.31664/z4khpu.26 